\title{
Ethnographic and Costume Regalia of Paari-gbiele Festival in Northern Ghana
}

\author{
Nyamawero Navei \\ Tumu Senior High Technical School,Tumu, Upper West Region, Ghana \\ DOI: https://dx.doi.org/10.51244/IJRSI.2021.8706
}

\begin{abstract}
Paari-gbiele is an annual post-harvest festival celebrated by the Sisaala indigenes of Tumu Traditional Area in the Sissala East Municipality of the Upper West Region of northern Ghana. It is celebrated annually to mark the end of successful farming season. It also serves as a momentous occasion for the glorification of the almighty God and the revered agriculturally related deities of the indigenes of Tumu Traditional Area for their protection and blessings of seasonal bumper harvests to the farmers. Paari-gbiele equally provides suitable platform for indigenous education, communal interaction and cohesion which significantly contributes to the revitalisation and promotion of the rich cultural ideals of the Sissala people of Tumu Traditional Area. In spite of the aforementioned sociocultural relevance of Paari-gbiele for which reason it is celebrated annually, there exists scanty or no documentary account on the ethnographic and costume regalia of the festival. The study therefore examined Paari-gbiele festival to establish its ethnographic foundation and the costume regalia utilised during its celebration. Guided by qualitative ethnographic design, the study collected data from thirteen (13) purposively sampled respondents (Chiefs and elders) in Tumu Traditional Area through the use of focus group discussion, unstructured observation and photography. The findings of the study were discussed using visual, descriptive and thematic analytical tools. The study concludes that the celebration of Paari-gbiele festival has a long-standing ethnographic background whereby its annual celebration is characterised by the adornment of glamorous traditional costume regalia with codified cultural connotations and relevance to the people of the Tumu Traditional Area. It is therefore recommended that the chiefs and elders of Tumu Traditional Area should endeavour to continuously deploy such unique traditional costume regalia during the annual celebration of Paari-gbiele to preserve their culture and harness the associated tourism and educational values of the festival.
\end{abstract}

Keywords: Cultural Semiotics, Costume Regalia, Ethnographic, Paari-gbiele Festival, Sissala, Tumu Traditional Area.

\section{INTRODUCTION}

I Africa and for that matter Ghana, traditional festivals, to some extent, are mandatory memorable sociocultural events that form an integral part of the cultural heritage of ethnic societies. O'Suvillan and Jackson (2002) agree that traditional festivals provide avenues for propagating the unique cultural heritage of local communities. Therefore, festivals are seen as undisputed communal fora for the promotion and reiteration of the actual place identities of local communities of which their cultural norms, beliefs and moral values are vividly revealed and promoted during the occasion (Selase \& Christopher, 2013; Adom, 2017). This means that traditional festivals are appropriate social platforms for showcasing and preserving the underlining cultural ideals of a particular society for its generations. Traditional festivals and their ethnographic foundations in specific African societies have been revealed by many scholars (Clarke-Ekong, 1997; Nortey, 2009; Kuuder, Adongo \& Abanga, 2012; Kemevor \& Duku, 2013; Akintan, 2013; Selase \& Christopher, 2013). In Ghana, there seemed to be a renewed and invigorating attention towards cultural events and traditions as increasingly observed in the yearly recurrent performance of local festivals (Clarke-Ekong, 1997) across the length and breadth of the country. The development of the cultural policy of Ghana (2004) seeks to further streamline, promote and preserve Ghanaian cultural heritage through traditional festivals for posterity. This provides additional considerable justification for the continual but diverse celebration of festivals in Ghana of which Paari-gbiele is a typified testimony.

Paari-gbiele festival is celebrated by the Sisaala people of Tumu Traditional Area in the Sissala East Municipality of the Upper West Region of northern Ghana. Generally, farming is the predominant occupation of the Sissala people of the Tumu Traditional Area. The Sissala people are amongst the leading players of the agricultural sector in Ghana and have continued to contribute immensely to the food basket of Ghana. Therefore, Paari-gbiele festival forms an integral part of the agricultural and sociocultural lives of the Sissala people in the Tumu Traditional Area. Although Paari-gbiele is annually celebrated, there exists scanty or no documentary account on its ethnographic foundation and costume regalia. Lack or scarcity of documentary accounts on Paari-gbiele festival coupled with the fact that the Cultural Policy of Ghana (2004) welcomes scholarly documentation and interpretation of festivals from institutions and researchers triggered the conduct of the study. The study therefore examined Paarigbiele festival to establish its ethnographic foundation and the costume regalia utilised during its celebration.

\section{REVIEW OF RELATED LITERATURE}

\section{Conceptual Framework}

The study was guided by concepts based on which African traditional festivals are founded. Generally, it is agreed that 
festivals are social events or phenomena encountered in virtually all human cultures (Falassi, 1987). However, the concepts of traditional festivals in Africa have links with the sociocultural evolutionary antecedents of Africans. Although, the etymological root of the term festival is originally derived from two Latin words, namely: "festum for public joy, merriment, revelry, and feria meaning abstinence from work in honour of the gods" (Falassi, 1987, p. 2), the earliest festivals in Africa "seem to have been connected with offerings to the dead" (Kemevor \& Duku, 2013, p. 54). Also, traditional festivals were primarily enacted by Africans to commemorate and venerate their ever-living ancestors; celebrate victories over dangerous animals and worship their gods/deities (Bonye, 2011; Akintan, 2013; Kemevor \& Duku, 2013). This means that the concepts behind festivals in African do vary but originate from marked sociocultural antecedents in the lives of a particular society. Kuuder, Adongo and Abanga (2012) reiterate that festivals have concepts and histories behind their celebrations. Kuuder, Adongo and Abanga further explain that traditional festivals come about as a result of festive occasions instituted in remembrance of certain turbulent circumstances suffered by a group of people who trace their roots to a common historical ancestry and how their forebears endured to overcome such turbulence. Kemevor and Duku (2013, p.54) typified that:

Different types of festivals are celebrated in the Ghanaian society to mark such historical seasons as the 'ohum' (name of a spirit) celebrated by the Akyem;'dwira'(purification) by the Akwapem; 'bakatue' (opening of lagoon) by the Edena; 'akwambo' (pathclearing) by the Gomoa, Ajumako, Ekumfi and Agona; 'aboakyer' (deer hunting) by the Effutu; 'homowo' (hooting at hunger) by the Ga; 'kotoklo' and 'nmayen' (eating millet) by the Krobo; 'agbeliza' (honouring cassava) by the Avenor; hogbetsotso (migration) by the Anlo; and 'damba' (birth and naming of the Prophet Mohammed)by the Dagomba and Mamprusi.

In addition, Prosterman (1995) opines that "traditional festivals are the past made present, which as historical constructs, may legitimize actions of the present" (as cited in Clarke-Ekong, 1997, p. 50). During the celebration of festivals, the inherited cultural identities of a people are reconstructed and repackaged to existing generations. According to Ngoma (2001), festivals have the additional capability to "contribute to the revival of our indigenous knowledge and cultures that were previously marginalised and demonised" (Bonye, 2011, p.33). This is because festivals "are vital mainsprings in the traditional education and the remit of the people's culture" (Akintan, 2013, p. 267). Bonye (2011) lists "drumming, dancing, art, songs, belief systems, values, norms and practices as vital components of culture that need to be preserved and maintained for posterity" (p. 33). In this wise, traditional festivals are periodically celebrated to preserve and maintain these cultural values from one generation to another (Nortey, 2009; Bonye, 2011; Selase \& Christopher, 2013; Akintan, 2013). This makes festivals appropriate platforms for periodic enculturation of the ideals of a society and/or social commemorative events meant to honour the forbears and gods of African society.

Per the discussion, it is the case that the originating roots of festivals in Africa and the concept behind their perpetuation vary from society to society but are largely influenced by the uniqueness of inherited social, cultural or religious events considered historic in the life of a society. Traditional festivals are therefore continually celebrated by the existing generation of community folks to commemorate their forebears or gods of their gallant contributions to the survival of their community.

\section{Costume Art Associated with African Festivals}

Festivals are by themselves the arts of man. Ododo (2001) concords that traditional festivals, in their entirety, are arts with embedded functional responsibilities in society. Amongst the various artefacts associated with African traditional festivals, traditional costume regalia are distinctive elements used by celebrants of festivals. According to Kemevor and Duku (2013), the costume regalia adorned by chiefs during festivals serve as unique visual communicative tools that clearly distinguish the social hierarchical status/authority of the chiefs to all and sundry at the durbar ground. During festivals, the Akan, Ewe and Ga of Ghana decorate their chiefs in gold ornaments and predominantly yellow 'kente'/'kete' clothes to symbolise prosperity, royalty, power, kingship, wealth and long life as a manifestation of their wealth and in the belief that they would be protected against evil spirits and enemies (Kemevor \& Duku, 2013). This means that the cultural symbolisms associated with the chiefs' costume regalia surpass their visual beauty. Saboro (2014, p. 150) observes that during the celebration of Feok festival by the Bulsa people of Northern Ghana, "one would notice the men dressed in war regalia, and brandishing of war implements accompanied by war drums". Ademin (2016) described the war costume regalia worn during the Feok festival as armours that war dancers wear during the festival which are made of a smock containing amulets, charms and talisman that protects and deflects bullets and evil spirits from the enemy. Also, Adom (2017) observes that during the celebration of the Apoo festival in Techiman in the Brong Ahafo Region of Ghana, groups of people dressed in anonymity fashions cum masks and walked directly to houses, workplaces and palaces of purported culprits of wrongdoings intending to expose those disturbing acts. Adom further reveals that the dress code has since been retained in the contemporary celebrations of the Apoo festival just to mimic how their ancestors dressed during the festival in times past. In a study on the artistic and cultural aspects of Homowo festival in Accra-Ghana, Nortey (2009) reports that costumes and dresses of various kinds were displayed during the celebration of the Homows festival bringing into focus stupendous artistic creations. Nortey emphasises that the wearing of different costumes such as Kente, smock and 
others throws the entire ceremonial grounds of the festival into a combination of colourful costumes which distribute to visual illusions in rhythmic beauty. Nortey further adds that the costume regalia of the priests, priestesses, chiefs and elders colours are mostly worn during the Homswo festival are white and believed to provide them with spiritual protection. Also, Eze and Akas (2015) observe that the costume regalia of the Egba festival of the Kokori, Isoko Local Government Area of Delta State in Nigeria form an integral part of the festival. They stressed that traditional costumes used for the Egba festival serve as identification; ward off evil spirits, for purification, to indicate social status, religious inclination, war, ritual, entertainment and to holistically communicate the cultural environment of the festival.

From the dialogue, it is clear that festivals are the embodiments of a variety of artefacts including costume regalia. Selase and Christopher (2013) however note that the celebrants and/or observers during festivals may see those artefacts (costume regalia) as mere elements which only ensure the continuity of the festival. However, costume regalia are embedded in the celebration of festivals to the extent that their negligence tends to spell doom for the festival.

\section{METHODOLOGY}

Generally, studies that focus on cultural festivals are ethnographic. Therefore, the study was guided by ethnographic design positioned within the parameters of the qualitative research approach. Ethnographic design is one of the best major designs of qualitative research because it focuses on the discovery, understanding and description of the culture of a group of people (Creswell, 2009; Mohajan, 2018). Guided by the ethnographic design, the study explored the ethnography of Paari-gbiele festival and some selected traditional costume regalia of the festival within the sociocultural context of the Sissala people of the Tumu Traditional Area. The suitability of the choice of the ethnographic design was further premised on the case that the researcher himself is a Sissala residing in Tumu and has over the years witnessed the celebration of Paari-gbiele festival. The study was therefore conducted from the insider's viewpoint. In generating in-depth data, the study elicited information from the Land-lord of Tumu, Paramount Chief of Tumu Traditional Area; three (3) elders in Tumu township and nine (9) Divisional Chiefs of Tumu Traditional Area amounting to a total of thirteen (13) respondents all in the Tumu Traditional Area. All the respondents were obtained through the use of a homogenous purposive sampling technique. The use of the homogenous purposive sampling technique for the selection of the respondents was to ensure that people with the best available knowledge (Pandey \& Pandey, 2015) on Paari-gbiele festival were sampled. The basis for sampling the Paramount Chief, Divisional Chiefs and key Elders was premised on the fact that chiefs are the custodians of the culture of the Sissala people in Tumu
Traditional Area who are counseled by their experienced elders regarding all traditional and cultural matters including Paari-gbiele festival. Data for the study were collected through focus group discussion which took the form of a phenomenological conversation - a dialogic way of questioning and answering. Unstructured observation and photography were also deployed in the data-gathering processes. The use of multiple data collection instruments ensured the authenticity and trustworthiness of the findings of the study as argued by Lincoln and Guba (1985). Data gathered through interviews were carefully transcribed, coded and reconciled with the available photographic data. The analysis and discussion of the findings of the study were qualitatively done using visual, descriptive and thematic analytical tools, all situated within the purview of the cultural semiotics of the people of the Tumu Traditional Area. Ethical considerations were upheld to gain the written consent and access to respondents, and to safeguard the anonymity of respondents during the analysis and discussion of the findings of the study except peculiar instances where respondents consented to full disclosure of their identities in verbatim intext citations and photographic displays.

\section{RESULTS AND DISCUSSION}

\section{Ethnographic Foundation of Paari-gbiele Festival}

Paari-gbiele is an annual post-harvest festival celebrated by the Sissala-indigenes of Tumu Traditional Area in the Sissala East Municipality in the Upper West Region of Northern Ghana. Paari-gbiele is a Sissala compound word meaning farming (Paari) celebration (gbiele). Its celebration is not only an annual cultural requirement but, it provides a common venue that draws Sissala farmers together from within the Tumu Paramountcy and other places to celebrate the end of successful farming season as well as thank the almighty God and their agriculturally related deities for the bumper harvests made of the farming season. The study established that Paari-gbiele, at a point in time, was an allencompassing Sissala festival. However, its celebration in recent times, is restricted to the Tumu Traditional Area even though it is still patronised by the generality of the Sissala people. One of the key respondents emphasised that Paarigbiele used to be for the entire Sissala community. Sissala from Walembelle Paramountcy, Gwollu Paramountcy, Zini Paramountcy, Pulima Paramountcy and other Sissala communities used to actively partake in the annual celebration of Paari-gbiele.

Although it was practically difficult to point out the exact date of the very commencement of Paari-gbiele, it was revealed that the festival could be said to have been initiated around early 1940 by the second Paramount Chief of Tumu Traditional Area known as Kuoro Wogrie Kanton II. It was recounted that after every successful farming season in every January, Wogrie Kanton II always invited his kith and kin, particularly communities from amongst his Issal clan (Chinchang, Taffiasi, Nachala, Bujan, Nabugubelle \& 
Dolibizon), to join the people of Tumu at his palace for end of harvest merriment. The festival was celebrated annually at the forecourt of the Tumu Kuoro palace where most of the guests came along with samples of their farm produce including; tubers of yam, millet, beans, and various interesting carvings such as hoe handles and others. After the demise of Wogrie Kanton II, his inheritor, Luri Kanton III saw that the celebration of Paari-gbiele was laudable and expanded the festival to, first of all, cover the entire Tumu Paramountcy, and secondly, to the other Paramountcies in Sissala land. As time went by, there were agitations by participating paramountcies for a rotation of the venue of the festival across the paramountcies in the entire Sissala land of which Luri Kanton III declined. However, while the festival was continually celebrated yearly in January, the Kanton family decided to set aside every $29^{\text {th }}$ of January, the death month and day of Wogrie Kanton II, to commemorate him (Wogrie Kanton II) for his contributions to the development of Tumu Paramountcy and for that matter Sissala land in general. The celebration of both Paari-gbiele festival and the Kanton commemorative day in January further created negative impressions in the minds of many of the participating Sissala Paramountcies. An elder of the Kanton family revealed that:

Kanton II was one of the leading known warriors who fought and succeeded the slave raiders in Sissala land during the days of slave trade. He was equally a famous hunter with unbroken records as far as hunting as an indigenous occupation in the Sissala land is concerned. Motivated by his achievements, an annual celebration was instituted by the Kanton family to commemorate his heroic and hunting prowess that contributed immensely to the development of Tumu Traditional Area and Sissala land by extension. And because Paari-gbiele and Kanton II commemorative day were celebrated in January, sometimes, both celebrations coincidentally fall on the same day or a week between them. Due to this, some of the chiefs thought that they were lured every year to Tumu to celebrate Kanton's commemorative day. After several agitations for rotation, the month for Paari-gbiele was rescheduled to March and that explains why the yearly Kanton's commemorative day is celebrated in January with Paari-gbiele in March. So, at a point, Paari-gbiele sort of went off until Kuoro Babini Kanton VI came and revived it and it has since been sustained. (N. Tommie-Kanton, 2020)

The study found that the annual performance of Paari-gbiele festival has significantly contributed to the revitalisation, preservation and promotion of the rich cultural ideals of the Sissala people of the Tumu Traditional Area. This finds expression in the reports of many scholars (Clarke-Ekong, 1997; Nortey, 2009; Kuuder, Adongo \& Abanga, 2012; Kemevor \& Duku, 2013; Akintan, 2013; Selase \& Christopher, 2013) that, traditional festivals are promoters of the cultural identity of a people. The respondents unanimously bemoaned that the introduction of both Christianity and Islam, Western education and culture in
Ghana has ignorantly led to the acculturation of many of the Sissala indigenes into accepting the practice of Christianity, Islam and Western cultures to the unfortunate abandonment of their indigenous cultural identity. For emphasis, one of the respondents stressed that:

Honestly, if not for Paari-gbiele, we would have lost out totally as a people. Religion had come and again, as a people, we misinterpreted religion, both Islam and Christianity, and thought what we did as a people was an outmoded practice. This had led to near extinction of the hitherto enviable Sissala culture. So, it is through Paari-gbiele you still find Sissala people recognising and coming to exhibit their indigenous cultures. I think now, if you begin going to our Sissala communities where Islam or Christianity used not to allow them to partake in Sissala indigenous cultural activities and funerals, they are beginning to learn to partake and/or perform our traditional funerals. Our traditional dance, particularly Bayilla, is coming back to life in some Sissala communities. It is partly because they have seen Tumu people exhibit it during the celebration of Paarigbiele festivals and our traditional funerals. Through Paarigbiele, the misperceptions some of our own have had about Sissala traditional cultural activities, is changing for good. And so, Paari- gbiele is really very significant. If we do not uphold Paari-gbiele as something that is bringing back our culture and arts, then, we will be a people without identity. (G.B. Baveru- Kanton, personal communication, December 28, 2020)

The degrading effects of Islamic and Christian faiths, and for that matter, Western education and culture on the indigenous cultural identity of the Sissala people of Tumu Traditional Area as espoused, are the sad uncontested sorrowful remnants of historical havocs created in Africa by the imperialists' colonial institutions. This resonates with Bringi's (2018, p.14) assertion that "the imperialisation and colonisation of Africa disrupted and attempted to completely erase the African identity". Bringi explains that African cultural values, governance systems, languages and entire being were mercilessly undermined and colonised, and this negatively impacted Africans profoundly. Afisi (2008, p.90) unequivocally concurs that "The crisis of African identity has overwhelmingly been traced to the advent of colonialism in Africa and, to say the least, the imposition of foreign cultural heritage on the people of Africa. This, the colonial institutions did, by misleading Africans into believing that their sociocultural values and education were archaic, uncouth, primitive or anachronistic, which must be cast-off and swapped with their European culture and education. This made Africans abandon their culture and system of education and replaced them with Western culture and education (Aze, 2014). The current phase of globalisation has further alienated Africans from their roots as the globalised media has made people all over the world look the same, worship the same God, speak the same language, wear the same type of dress, enjoy the same type of music, and eat the same type 
of food (Aze, 2014). This has therefore pushed Africans into a serious conflict situation over what constitutes their real identity and, to some extent, has recreated a fake identity that is neither Eurocentric nor African. So, therefore, the annual celebration of Paari-gbiele festival by the Sissala indigenes of Tumu Traditional Area, as unanimously consented by the respondents, remains one of the surest ways of revitalising, promoting and preserving their cultural dignity for posterity.

\section{Costume Regalia of Tuти Kuoro (Chief) during Paari-gbiele} Festival

The costume regalia of the Paramount Chief of Tumu Traditional Area for the occasion of the Paari-gbiele festival have codified cultural connotations. The study revealed that the climax of the Paari-gbiele festival is one of the few occasions that the Paramount Chief of Tumu Traditional Area is costumed in full-scale traditional regalia as observed in Figure 1B. One of the respondents explained that:

The climax of Paari-gbiele festival is a notable rare occasion the Paramount Chief of Tumu Traditional Area is actually costumed in full regalia and sits in a throne before his subjects and invited guests. Apart from the enskinment costume regalia worn over his three-piece smock costumes, if you actually go and examine the sitting place of the Paramount Chief, you would see a pile of animal skins made of cow, lion and antelope which are usually arranged to form the throne for the chief to sit on. (K. Tommie, 2020)

The use of multiple animal skins (Figure 1A) to form the throne of the Paramount Chief of Tumu for the occasion depicts the skin as the symbol of authority as far as the chieftaincy traditions of the Sissala people of northern Ghana is concerned. This is in tandem with the observation made by Awedoba (2015) that northern chiefs of Ghana sit on thrones made of a pile of skins.

A cursory study of the costume regalia of the Paramount Chief of Tumu (Figure 1B) reveals a set of three-piece smock costume known as Jaba by the people of Tumu and complimented with a red upright hat - an official Sissala traditional costume reserved for a high-ranking royal class. The red flowing costume with frontal opening worn over the three-piece smock regalia with its complimentary red hat (known as Bilinbafien in Sissali) as observed in Figure 1B is said to be the traditional enskinment dress regalia of Tumu Paramountcy. The red apparel together with its befitting red hat as adorned by the Paramount chief (Figure 1B), symbolically defined him as the senior-most chief of the Tumu Paramountcy. The study ascertained that red hats are occasionally worn by the Paramount Chief, particularly, when in council with his elders or during classified social gatherings such as Paari-gbiele festival. In any of such occasions, none of his subjects including the lower chiefs is culturally allowed, knowingly or unknowingly, to wear a similarly red hat like that of the Paramount Chief of Tumu Traditional Area. Any subject who acts contrary to this means such a person is disrespectful of the High chief and would either be fined or punished with spiritual ailment. This assertion finds exact expression in the report of Acquaah, Amissah and Yankson (2017) which reveals that red hats are title hats that must be worn by only the title holders particularly chiefs who have reached the highest of their line of elevation. The study further ascertained that the positioning of the chief's hat (stiffly erected and pointing to the sky) (Figure 1B) symbolises his undoubted supremacy over all other lower chiefs and subjects of the Tumu paramountcy. This resonates with available studies which assert that during public/social gatherings or durbar of chiefs in northern Ghana, the wearing of hats in stiff and erect positioning symbolises the supremacy of the wearer except God or superior ruler with no co-equal (by Essel \& Amissah, 2015; Acquaah, Amissah \& Yankson, 2017). Another important symbol of the chief's regalia is his walking stick conspicuously placed on his laps (Figure1B). The study found the walking stick to be an inseparable part of his daily cultural fashion regalia. In Tumu culture, walking stick is one of the symbols of the chieftaincy title. For this symbolism, it is incumbent for all legitimately enskinned chiefs to carry their walking sticks to all social gatherings as the practice defines them as title men and chiefs of their respective villages/towns. One other key component of the chief's regalia is the wearing of the silver medallion (necklace), unanimously referred to as Number by respondents. The study established that the medal (Number) was given to the Paramount Chief of Tumu Traditional Area by the colonial government of Ghana as the symbol of recognition and authority.

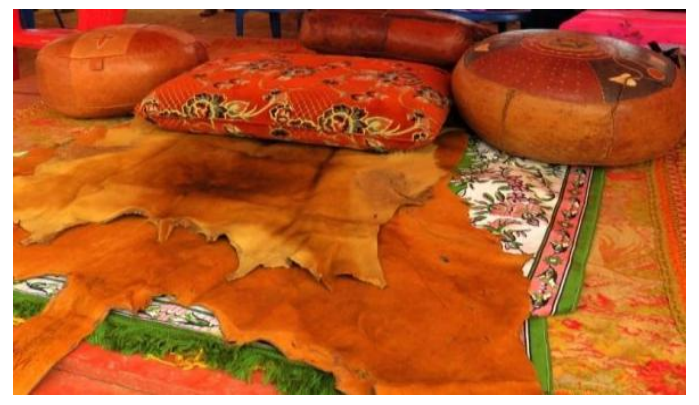

A

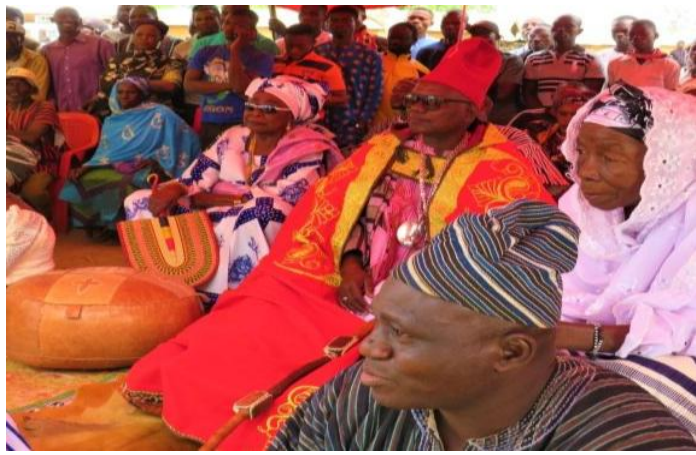

B

Figure $1(\mathrm{~A} \& \mathrm{~B})$ : Stage and Costume regalia of Tumu Kuoro (Chief) during Paari-gbiele Festival (Image Courtesy: Ayamga Fatawu, 2018) 
War Costume Regalia Showcased during Paari-gbiele Festival

The presence of European motivated Trans-Atlantic slave raiders in Africa, particularly, in the northern enclave of Ghana, created a sense of insecurity for human survival around the nineteenth century. According to Saboro (2014, p. 22) the nineteenth-century became an important period in the history of northern Ghana mainly due to the rise of the activities of Zabarima slave raiders and traders, notably Babatu and Samori Toure, Alfa, Hanno and Gazari. The dehumanising activities of the slave raiders at the time included kidnapping and/ or killing of many people in northern Ghana including people from the Sissala area. This led to the adoption of several indigenous resistance mechanisms for self-protection against the slave raiders (Agamba, 2006; Koomson, 2010; Duut, 2014; Saboro, 2014; Ademin, 2016; Saboro, 2016). One of such resistance systems adopted by the Sissala people of Tumu Traditional Area to disarm and/or dislodge the slave raiders was the initiation of an army of local worriers made of energetic and spiritually fortified abled-men. The spiritual powers of the warriors were largely drawn from their ritually produced smock regalia referred to as Sebse garin (amulets costume) in Sissali (Figure 3A\&B). The study found that the war costume regalia adorned by the warriors during Paari-gbiele (Figure 2A\&B, $3 A \& B)$ comprised ritually dyed smocks with their hats which are variously characterised by attachments of leather-made amulets, charms and mystical accouterments believed to contain unparalleled spiritual powers capable of fortifying the wearer against all forms of attacks (physical or spiritual) including arrows from bows and bullets from guns during warfare. The study found that the amulets, talismans and charms observed on the war costume regalia (Figure 2A\&B, $3 A \& B)$ are mostly encased in the skins of lion, tiger, leopard and cat. Such animals are believed to be the most powerful animals and the kings of the animal kingdom. Therefore, ritually using their skins as amulets, charms and talismans mysteriously imbue the combined spiritual powers of such animals on the war costume making the attire extraordinary and spiritually endowed to empower its wearer against all negative forces. This is corroborated by the findings of Ademin (2016) who described the war costume regalia worn by the Bulsa warriors during the Feok festival in northern Ghana as traditional armour-costume made of smock containing amulets, charms and talisman that has the potency to protect and deflect bullets and evil spirits. The respondents proclaimed that the war costume regalia of the warriors of the various communities in the Tumu Traditional Area are highly revered and, many a time, pacified through ritual sacrifices before their adornment to provoke their fullest spiritual powers in ensuring adequate protection for the wearer. The adornment of war costumes comes with taboos and restrictions. According to A. Bayorbor (personal commutation, December 28, 2020):

Any violation of the taboos of the war costume could lead to madness, mysterious sickness or death depending on the gravity of the violation. War costumes are not worn anyhow as it is with ordinary clothes. With war costume, particularly the inherited ones, adequate education must be provided on how to use them. Whether one needs to sit, stand, kneel, squat or lie before wearing the costume, must be made known to its inheritor. Even the incantations to make before wearing the costume, when leaving the room, when returning into the room and how the costume is unworn after its usage are conditions that must strictly be observed.

During the celebration of Paari-gbiele, the war costume regalia of the various communities in the Tumu Paramountcy are adorned for the performance of the Ba-Yiila (war songs/dance) to demonstrate the war-like identity and the inherited brevity of the people of Tumu Traditional area. The respondents explained that Ba-Yiila is a Sissala compound word meaning men songs (Ba-man \& Yiila- songs) strictly observed by only well dignified, energetic, brave and spiritually-endowed men of the society. It was emphasised that women were strictly exempted from the Ba-Yiila dance in time past with the conception that they are generally not brave enough to withstand the sight of human blood and killings during warfare. It is for this, and many other cultural considerations that women were excluded from the war dance. Even men, who fall within the sons' category, irrespective of their ages, do not qualify for full-scale $B a$ Yiila dance. The performance of Ba-Yilla by the Tumu warriors was always climaxed with the public eating of live animals (Figure 3A\&B). Public eating of live animals by the Tumu warriors is an old traditional ritual rarely performed during the traditional funeral rites of few renowned elderly men and replicated during the Paari-gbiele festival. The respondents indicated that live dog, goat or sheep is mostly used to punctuate Ba-Yilla (war dance) during male funerals. Although any of the aforementioned animals could be eaten alive at the traditional funeral rites of elderly deceased men, a live dog could be requested and eaten at the funeral rites of a high-ranking elderly male member of the society (Figure 3A). The respondents unanimously added that dogs are spiritual animals with four eyes (spiritual foresight) because they see both in the daytime as well as nighttime. This explains why dogs have since become trusted familial and communal guards in Tumu Traditional Area nurtured to drive away malevolent spirits through aggressive barking particularly during nighttime. Also, A. F. Bayorbor (personal communication, December 22th, 2020) added that "dogs are spiritual animals and a deity that accepts dog's sacrifice means that such a deity is spiritually powerful and potent. Because of this, most of our powerful deities such as; Bafurumo, Afurumo and Jabuni accepts the sacrifice of dogs". The eating of dog meat for spiritual reasons is not only limited to the Sissala people of Tumu Paramountcy only but it is of African lineage. Existing studies report that dog meat is eaten for rituals and/ or spiritual reasons in parts of Africa (Eric \& Oliver, 1982; as cited in Ehimiyein, Audu \& Ehimiyein, 2014; Garba, Dzikwi, Okewole, Chitunya-Wilson, Tirmidhi, Kazeem \& Umoh, 2013; Gurumyen et al 2020). It 
is emphasised that the consumption of dog meat protects people against attacks of witches (Garba et al, 2013; Ehimiyein, Audu \& Ehimiyein, 2014; Gurumyen, Akanle, Yikwabs \& Nomishan, 2020). Owing to the spiritual prowess of dogs as aforementioned, eating live dogs during Paarigbiele festival (Figure 3A), signifies the brevity and machismo of the Sisaala people of Tumu Traditional Area, a reflection of the caliber of warriors that defended their forebears during the days of slavery. It was emphasised that the spiritual powers embedded in the war costumes coupled with other edible traditionally prepared substances are used in taming and killing the live dog for the blood and the raw meat to be eaten without negative impact on their health.

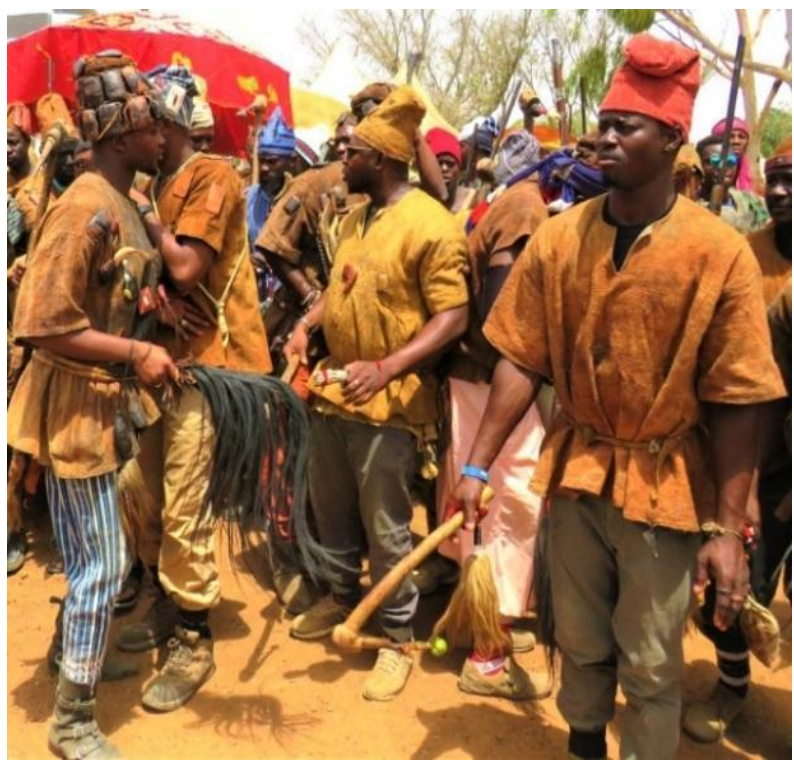

A

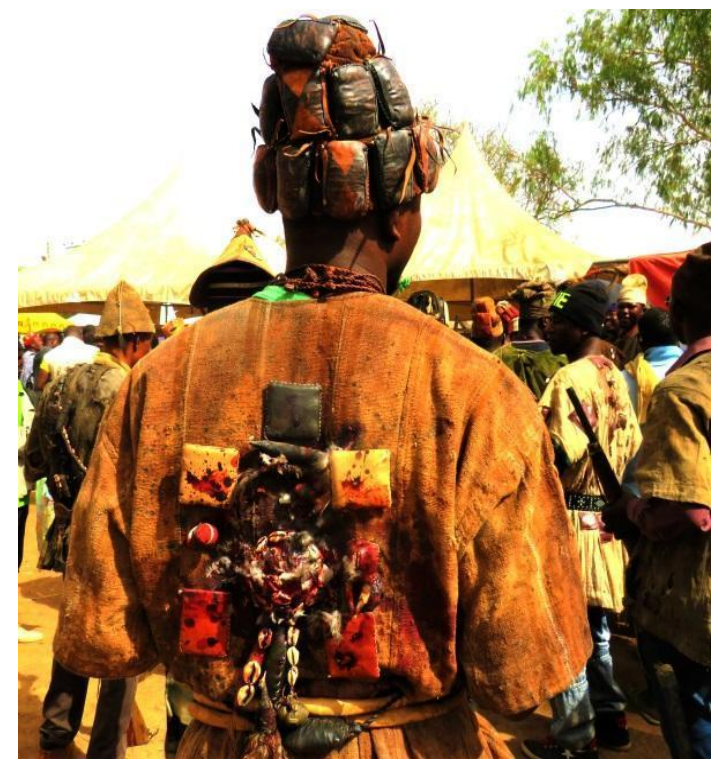

B

Figure 2 (A\&B). War Costume Regalia of the People of Tumu Worn during Paari-gbiele Festival (Image Courtesy: Ayamga Fatawu, 2018).

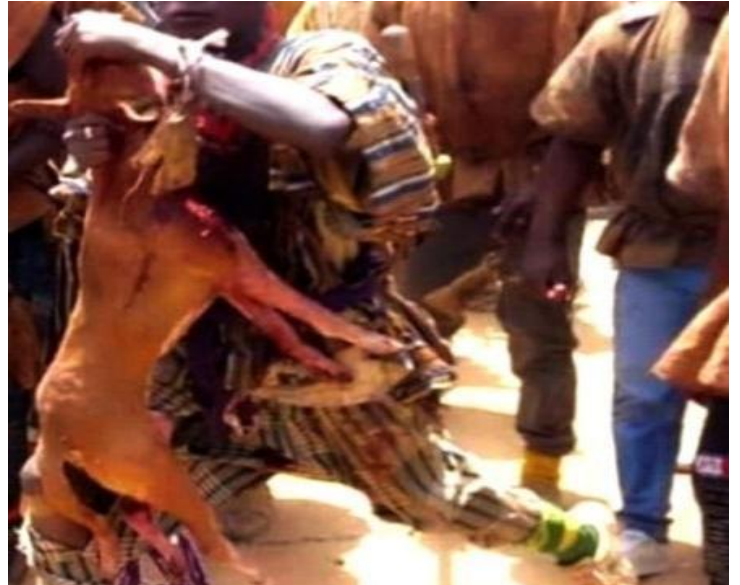

A

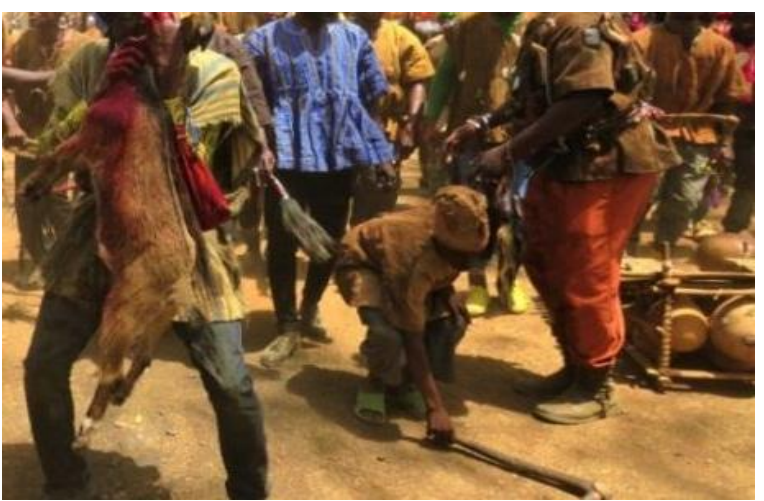

B

Figure 3 A\&B: Ritual Eating of Live Animals during Paari-gbiele festival by Tumu Warriors (Image Courtesy: Ayamga Fatawu, 2018).

Nankpaana (Hunters) Costume Regalia Exhibited during Paari-gbiele Festival

Hunting is said to be the initial indigenous occupation that sustained the Sissala people of the Tumu Traditional Area for several years before subsistence farming emerged. Phillipson (2005), as cited in Manyanga and Pangeti (2017, p.277) confirms that "palaeontological and archaeological evidence suggests that human ancestry in southern Africa dates back four million years, and throughout this time, humanity has hunted for survival". As an ancient occupation, hunting expedition in the olden days was risky to embark on because it was done in thick forests that habited so many harmful creatures like lions, snakes and the likes and, many a time, slave raiders laid ambush in the ecological covers to kidnap innocent people for their slavery business as revealed by the study. The study ascertained that hunting played a crucial role in the migration history of the ancient people of the Tumu Traditional Area. It was revealed that the forebears of the indigenous people of Tumu Traditional Area, particularly Tumu, in the search for a friendlier environment moved, through hunting, from a hunting community known as Kaha in the northern region of Ghana to its present location. Amid the overwhelming dangers associated with hunting and the 
case that human survival at the time was seriously threatened, the forebears of the Tumu Traditional Area resorted to the use of spiritual mechanisms or fortification to subdue the lifethreatening dangers associated with hunting. Key amongst these spiritual mechanisms was the ritual preparation and adoption of traditional costume regalia (Figure $4 \mathrm{~A} \& \mathrm{~B}$ ) which are spiritually powerful enough to protect the hunters in overpowering the animals, especially the wild ones, as well as ensuring successful hunting expeditions. The respondents unanimously stressed that the costume regalia for hunters (Figure $4 \mathrm{~A} \& \mathrm{~B}$ ) were made of ritually dyed smocks studded with multiple amulets, charms and talismans believed to possess excessive spiritual powers to protect the hunters against the attacks of dangerous wild animals and slave raiders. In providing clarity on the enormous spiritual powers possessed by the costume regalia of hunters in the Tumu Traditional Area and how those spiritual powers were practically brought to bear during hunting expeditions, one of the respondents had the following to add:

Some of the costume regalia of hunters have multiples of diverse spiritual powers emanating from the copious charms, amulets, talismans including Bakuruma [name of a powerful male deity] all affixed to the hunter's costume. For instance, the powers of the Bakuruma amulet on the costume could be invoked by the mention of Bafurumo to command down an attacking animal such as bush pig, lion, elephant, tiger and others. At each loud Bafurumo command, no matter what, the animal must fall. And, at each falling, the limb on which the animal falls, gets broken. This weakens the animal and gives space for the hunter to reload his gun severally and to repeatedly shoot the animal until it completely dies. (A. F. Bayorbor, personal communication, December 28, 2020)

The description given about the spiritual nature of the hunters' costume regalia finds expression in the findings of a study conducted on the Bambara people of Mali by Akinbileje (2014) where it was revealed that shirts meant for hunting appeared brown and adorned with amulets, horns and other traditional medicine to help improve the hunter's effectiveness. Besides the spirituality of the hunters' costume regalia, it was ascertained that the colour scheme adopted for the hunter's costumes such as; brown and black was deliberately done to disguise the appearance of the hunters and make them unidentifiable in the eye of the animals. "Even at a close distance, a hunter in such brownish/reddish or blackish dyed costume appears as though it is dried leaves or another animal with black colouration in the eye of the targeted animal" (A. F. Bayorbor, personal communication, December 22th, 2020). This visual deception created, allows hunters to get closer to the prey, aim and shoot at the appropriate part leading to its death.

It was further added that the costume regalia for hunters contain certain distinguishable ranks attained in the life history of a hunter which is not the case of war costumes. The hunting occupation which begins with the killing of bush fowls such as partridges does not need an official hunting costume. But, when a beginner-hunter progresses to the killing of antelopes and other smaller animals, a hunting costume (Figure $4 \mathrm{~A} \& \mathrm{~B}$ ) is prepared for him but without any rank indicated. Also, when the hunter graduates to the killing of bigger and wild animals such as buffalo, he earns rank-I of the hunting occupation which is indicated at the back of the costume with the fur and other classified parts of the animal. Additionally, the successful killing of wilder animals such as bush pig, elephant and others warrants promotion of the hunter to rank-II which is conspicuously added to the first rank. The third rank which is the last but highest of the hunting ranks comes with the killing of animals such as; lions, tigers or leopards which are considered to be the wildest in the bush. Parts of the skin, teeth and others of such animals are symbolically put together to constitute the rankIII, the last rank, which is added to the existing titles. During the celebration of the Paari-gbiele festival, the various costume regalia (Figure $4 \mathrm{~A} \& \mathrm{~B}$ ) of hunters are worn for the Nankpana (hunters) dance to reveal the hunting prowess of the people of Tumu Traditional Area.

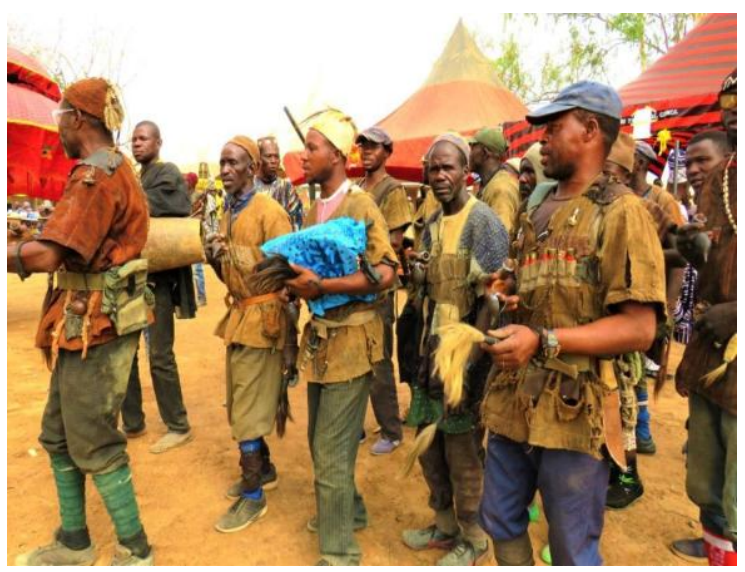

A

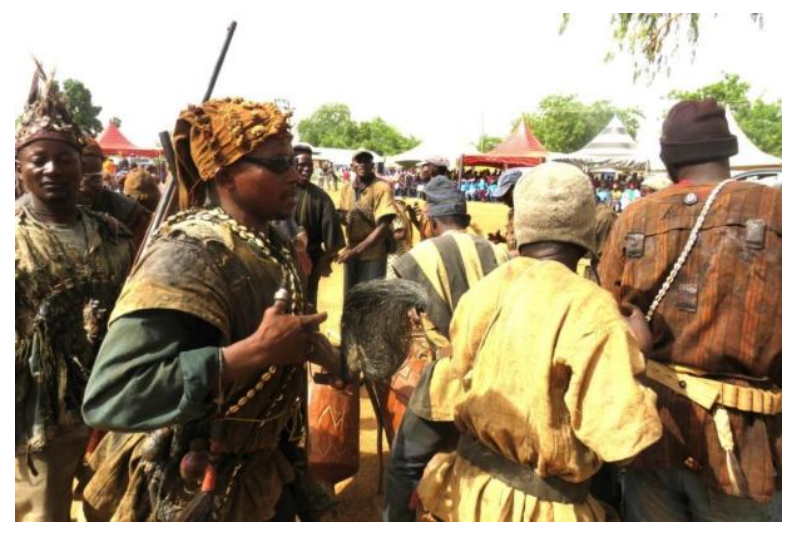

B

Figure 4A \& B. Hunters' Costume Regalia Displayed during Nankpana (hunters) Dance at Paari-gbiele Festival (Image Courtesy, Ayamga Fatawu, 2018). 
Costume regalia for the Drum Performers Displayed during Paari-gbiele Festival

Ghanaian traditional music and dance have cultural underpinnings, for which reason, they are performed during traditional festival occasions. The indigenous musical instruments (drums, bells, xylophones, sticks, and others), localised costumes as well as indigenous dance steps and movements showcased by people during festivals help in defining their culture. According to Kquofi, Ndah and TabiAgyei (2015), during the celebration of the yam festival, the cultural identity of the people of Logba is displayed through their musical ensemble. Aryetey (2002), as cited in Kquofi et al (2015) corroborates this by explaining that traditional drumming and dancing which is part of Ghanaian culture is used to promote the cultural identity and heritage of Ghana. In this study, it was found that the annual celebration of the Paari-gbiele festival always witnessed the cultural display of Tempening/Gugong (drum) Yiila (dance) considered as one of the age-old traditional performances of the people of Tumu Traditional Area. Although Tempen and GugoYiila may ordinarily be described as drum performance, the respondents explained that the two are different in terms of the nature of the drums, style of drumming, type of songs and performances associated with each of them. Tempen Yilla is played from a pair of talking drums with hollow bases resting on wooden supports (Figure 5A) while the Gugo is an ordinary drum with dual drumming sides (both ends) which is laid on the ground and played (5B). Irrespective of the differences between the Tempen and GugoYiila, the costume regalia of both performances are similar. Even in some instances, both the Tempening and Gugong drums are combined for Tempen and Gugo Yiila (drum performance) as such combinations introduce an imaginable melodious sound for unending performance. A zoom-in of Figures 5A and 5B revealed skirts and singlets/sleeveless shirts as the costume regalia adorned by the performers of Tempen and Gugo Yiila during the celebration of Paari-gbiele festival. In both instances (Figure 5A\&B) all the performers (men \&women) wore loosely ornamented skirts to allow for free and rigorous movements of the legs and to ensure admirable uniformity. Even though the costumes of the Tempen and Gugo Yiila performers were initially made of smock skirts and sleeveless shirts which were carefully decorated with cowries, in these contemporary times, ordinary Ghanaian fabrics are used to fabricate the skirts as observed in figure $5 \mathrm{~A}$ and $5 \mathrm{~B}$ respectively. The study further found that the costume regalia of the Tempen and Gugo Yiila performers are not ritually produced and therefore do not contain any charms, amulets and talismans as identified in figures $1 \mathrm{~B}, 2 \mathrm{~A} \& \mathrm{~B}, 3 \mathrm{~A} \& \mathrm{~B}$, $4 \mathrm{~A} \& \mathrm{~B}$.

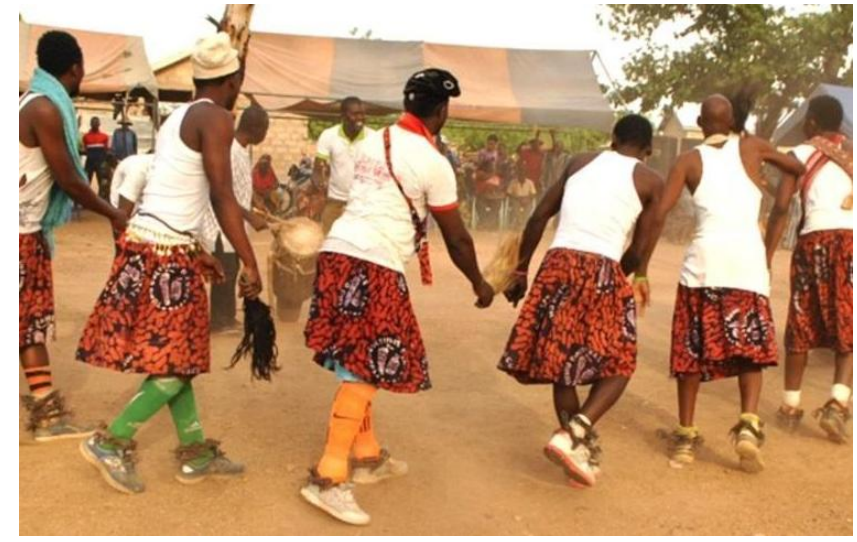

A Tempen Yiila

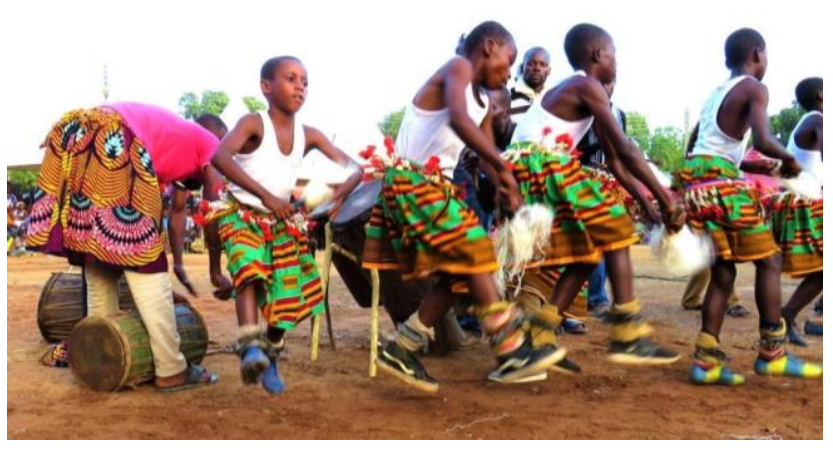

B. Gugo Yiila

Figure 5(A\&B): Costume regalia of drum performers (Image Courtesy: Yahaya Kanton, 2016)

\section{CONCLUSIONS}

Paari-gbiele is an annual post-harvest festival celebrated by the Sissala-indigenes of Tumu Traditional Area in the Sissala East Municipality of Northern Ghana. The ethnographic foundation of Paari-gbiele has links with the second Paramount Chief of Tumu Traditional Area (Wogrie Kanton II). Its celebration was initially limited to the Issal clan in Tumu Traditional Area but was later broadened to encompass the entire Sissala land. However, in recent times, Paari-gbiele is restricted to the Tumu Traditional Area even though it is still patronised by the generality of the Sissala people. The annual celebration of Paari-gbiele festival provides the platform for indigenous education, communal interaction and cohesion which significantly contributed to the revitalisation and promotion of the rich cultural ideals of the Sissala people of Tumu Traditional Area with attractive tourism potentials. Therefore, the study recommends that the Chiefs and Elders of the Tumu Traditional Area should endeavour to annually perform Paari-gbiele festival to deepen the revitalisation and promotion of the cultural ideals of the Sissala people of Tumu Traditional Area to propel development.

The celebration of Paari-gbiele festival is usually characterised by the adornment of glamorous traditional costume regalia which have codified cultural connotations and relevance to the people of the Tumu Traditional Area. 
Through the costume regalia, the social status of the Paramount Chief Tumu of Traditional Area could be distinguished from others. Also, the spirituality of the warriors and hunters of Tumu Traditional Area is communicated through their costume regalia whereas, the traditional costume regalia of drum performers during Paarigbiele festival were revealed. Therefore, the chiefs and elders of Tumu Traditional Area should endeavour to continuously deploy such unique traditional costume regalia during the annual celebration of the Paari-gbiele to preserve their culture and harness the associated tourism and educational values of the festival.

\section{REFERENCES}

[1] Acquaah, S. Amissah, E. R. K. \& Yankson, P. G. (2017). Dress aesthetics of smock in northern Ghana: Form, function, and context. Journal of Textile Engineering \& Fashion Technology,1(2), 68-77.

[2] Ademin, A. Y. (2016). Indigenous resistance to slavery by the Builsa people of northern University of Ghana, Legon.

[3] Adom, D. (2017). Strategic adaptation of traditional festivals for the sustainable development of the biodiversity of local communities in Ghana. Open Journal of Social Sciences, 5, 6994.

[4] Agamba, J. J. (2006). Beyond Elmina: The slave trade in northern Ghana. Ufahamu: A Journal of African Studies 32(1-2). 39-72.

[5] Akinbileje, T.Y. (2014). Symbolic values of clothing and textiles art in traditional and contemporary Africa. International Journal of Development and Sustainability, 3(4), 626-641.

[6] Akintan, O. A. (2013). Traditional religious festivals and modernity: A case study of female oriented cults annual festivals in Ijebuland of south western Nigeria. International Journal of Humanities and Social Science, 3(9), 267- 276.

[7] Awedoba, A.K. (2015). The Peoples of Northern Ghana. National Commission on Culture.

[8] Bonye, S. Z. (2011). The role of traditional festivals in action planning, advocacy and social accountability. World $J$ Young Researchers, 1(3), 32-39.

[9] Clarke-Ekong, S. F. (1997). Traditional festivals in the political economy: The case of contemporary Ghana. Journal of Social Development in Africa, 12(2), 49-60.

[10] Creswell, J. W. (2009). Research Design: Qualitative, Quantitative and Mixed Method Approaches (3rd Ed.). Los Angeles: SAGE Publications.

[11] Duut, G. N. (2014). Feok war dance festival: Addressing security concerns in upper east region,Ghana (Doctor of Philosophy dissertation). University of Education, Winneba.

[12] Ehimiyein, A, Audu, S. \& Ehimiyein, I. (2014). The role of dog trading and slaughter for meat in rabies epidemiology with special reference to Nigeria- a review. Journal of Experimental Biology and Agricultural Sciences, 2(2), 130- 136.

[13] Essel, O. Q. \& Amissah, E. R. K. (2015). Smock fashion culture in Ghana's dress identity-making. Historical Research Letter, 18, 32-38.

[14] Eze, C. P. \& Akas, N. C. (2015). Costume and make up, as a tool for cultural interpretation: A study of Egba festival of the Kokori,
Isoko local government area of Delta State. Arts and Design Studies, 36, 22-34.

[15] Falassi, A. (1987) Festival: Definition and morphology. In: Falassi, A., Ed., Time out of Time, University of New Me-xico Press, Albuquerque.

[16] Garba, A, Dzikwi, A. A., Okewole, P.A, Chitunya-Wilson, B. B., Tirmidhi, A, B, Kazeem, H. M. \& Umoh, J. U. (2013). Evaluation of dog slaughter and consumption practices related to the control of rabies in Nigeria. Journal of Experimental Biology and Agricultural Sciences, $\quad$ 1(2S), 125-130

[17] Gurumyen, B. D., Akanle, O., Yikwabs, Y. P. \& Nomishan, T. S. (2020). Zootherapy: The use of dog meat for traditional African medicine in Kanke local government area, plateau state, Nigeria. Journal of Tourism and Heritage Studies, 9(2), 1-14.

[18] Kemevor, A. K. \& Duku, F. K. (2013). Art: The pivot of Ghanaian festivals. Journal of African Arts and Culture. 1(1). 5362.

[19] Koomson, P. B. (2010). A vision of self-redemption: A thematic study of resistance to slavery in the works of two contemporary Ghanaian writers (Master of Philosophy Thesis). University of Cape Coast.

[20] Kquofi, S., Ndah, S. \& Tabi-Agyei, E. (2015). Serendipitous socio-cultural dynamics of Logba traditional musical ensembles in Ghana. European Journal of Research and Reflection in Arts and Humanities, 3(1), 13-25.

[21] Kuuder, C.W., Adongo, R. \& Abanga, J. (2012). The sociocultural significance of the Kakube festival of the dagara of Nandom traditional area in Ghana. GJDS, 9(2), 103-124.

[22] Lincoln, Y. S., \& Guba, E. G. (1985). Naturalistic Inquiry. Beverly Hills, Calif: SAGE.

[23] Manyanga, M. \& Pangeti, G. (2017). Precolonial hunting in southern Africa: A changing paradigm. In M. Manyanga \& S. Chirikure (Eds.), Archives, Objects, Places and Landscapes: Multidisciplinary Approaches to Decolonised Zimbabwean Pasts (pp.277-285), Langaa: Bamenda.

[24] Mohajan, H. K. (2018). Qualitative research methodology in social sciences and related subjects. Journal of Economic Development, Environment and People, 7(1), 23-48.

[25] Nortey, s. (2009). The Homows festival in Accra: Its artistic and other cultural aspects (Doctor of Philosophy Dissertation). University of Science and Technology, Kumasi.

[26] Ododo, S. E. (2001). Theatrical aesthetics and functional values of Ekuechi masquerade ensemble the Ebira people in Nigeria. African Study Monographs, 22(1)1-36.

[27] O'Suvillan, D. and Jackson, M.J. (2002) Festival tourism: A contributor to sustainable local economic development? Journal of Sustainable Tourism, 10, 325-342. Republic of Ghana. (2004). The cultural policy of Ghana. National Commission on Culture.

[28] Pandey, P. \& Pandey, M. M. (2015). Research methodology: Tools and techniques. Bridge Center.

[29] Saboro, E. (2014). Slavery, memory and orality: Analysis of song texts from northern Ghana ( $\mathrm{PhD}$ dissertation). University of Hull.

[30] Saboro, E. (2016). The burden of memory: Oral and material evidence of human kidnapping for enslavement and resistance strategies among the Bulsa and Kasena of Ghana. Africology: The Journal of Pan African Studies, 9(4), 111- 130.

[31] Selase, G. R. \& Christopher, M. (2013). The role of art forms in the celebration of festivals: A case study of Asogli yam festival, Volta region, Ghana.Arts and DesignStudies, 12 35-40. 